\title{
ロシアの原油・ガス輸出政策
}

\author{
酒 井 明 司 \\ （三菱商事（株）業務部ロシア担当次長）
}

\section{Crude Oil and Natural Gas Export Policy of Russia}

\author{
SAKAI, Satoshi \\ Deputy General manager, Regional Strategy \& Cordination Dept, Mitsubishi Corporation
}

\begin{abstract}
We can find easily dozens of media and academic articles over the past 1-2 years that foretell and warn of Russia's aggressive foreign policies to her neighbours by means of her energy-exporting power in oil and gas. Many of them are the products of the gas dispute between Russia and Ukraine in the early 2006, which also reminds some authors of Russia's oil cut-off of the Baltic countries in the early 90's. In their arguments they seem to share a common understanding that Russia has firm intentions and aims in her foreign policies-to decelerate, if not to exclude fully, democratization of her FSU neighbours and to extract maximum diplomatic concessions from them and the EU members, concluding that her oil and gas resources are political instruments these purposes.

After having a look at each oil/gas pipeline project of Russia, however, we feel this conclusion may not match reality. In this article the current main oil and gas pipeline projects of Russia (to Europe-BTS, Burgas-Alexandropoulis, Nord Stream, and South Stream; and to Asian countries-East Siberia-Pacific Ocean (VSTO) and Altaj) are briefly reviewed, and it is hard to see her aggressive diplomatic intentions in them. The main motive of new pipeline construction by Russia to Europe is to bypass as many transit countries as possible or to avoid transportation bottlenecks. They are of a commercial character rather than a political one, though the current transit countries which may lose their position by newly routed pipelines of Russia fear the theoretical worst that they will be under a full energy supply control by Russia. The construction plans of eastbound pipelines to Asian countries and the Pacific Ocean have a primary task to develop the areas of East Siberia and the Far East of Russia, accompanied by again commercial tactics in avoiding transit countries and a single destination route of the energy export.

We have to pay more attention to the fact that Russia's energy export policy is hardly reliable in the world energy market, not because of her politicized aggressive stance to consumers but because it only plays a passive role against what the world
\end{abstract}

Keywords: Energy policy, Pipeline, Putin government, By-pass route, Oil and gas export 
market expects to one of the main oil and gas exporters. Though Russia reacts to given conditions like transit countries, she does not seem yet to involve herself into market coordination and adjustment of demand/supply balances in cooperation with other producers and consumers.

\section{はじめに}

資源価格上昇の中で原油や天然ガスの輸出大国であるロシアの世界市場に占める地位は高 まっており，その資源輸出政策（主に原油とガス）に付いては，国威発揚或いは対外政策の手 段として天然資源を利用する，と言ったロシアへの批判的な側面がこれまで強調されてきてい る。国際政治の様々な局面でその西側との対立が目立ち始める中で, パイプライン輸送での通 過国問題やガス OPEC 創設の可能性の議論から資源大国ロシアの像が急浮上し，米国・EUよ り「エネルギーを他国支配の手段として使う」ものとして警戒と批判を受け始め，これは 2006 年初頭のウクライナ向けガス輸出の一時停止措置で加速された ${ }^{(1)}$ 。

果たしてロシアに他国支配の手段としての扱いも含め, 原油・ガスの輸出で確固とした国策 が存在するのだろらか。この点を同国の現在の欧州，アジア双方へ向けた輸出政策や新規輸出 経路への考え方を概観しつつ検証したい。

\section{1 プーチン政権の原油・ガス輸出政策}

原油・ガスの輸出に関するロシア政府の方針を明示するのは，プーチン政権の下では 2000 年 11 月の「2020年までのエネルギー戦略」(2) とその改訂に当たる上述の 2003 年版 ${ }^{(3)}$ となる。 前者は前政権の政策を踏襲し外資への依存の必要性を明示しつつ健全な輸出産業としての発展 への願望が述べているに過ぎず，原油・ガス輸出政策でのプーチン政権の新機軸をその中に見 ることは未だできない。後者は原油の国際価格が急騰し始めた時期に策定され，その中で資源 分野での対外方針として以下を挙げている：

（1）国内需要を満たした上でのエネルギー資源輸出の増加。

(2) 輸出先と輸出方法の多様化（LNG 及び GTL）。

（3）ロシア企業によるエネルギー資源分野への対外投資と逆に国内エネルギー資源開発・輸

送・加工への外資の受け入れ。

（4）世界の資源価格安定のための生産・消費国間の協力関係への配慮。

その後, 燃料類の輸出額は増加の一途を巡り，2006年で原油・石油製品・ガスに石炭を加 えた輸出額 \$1876 億はロシアの輸出全体の $62 \%$ を占め, 2007 年上半期もこの割合はほぼ 60\% となっているが，上記の 2003 年の方針の基となる諸予測数値は現在に到るまで大きな变 更はなされていない（2008 年末までに 2030 年までのエネルギー戦略を策定予定 $\left.{ }^{(4)}\right)$ 。

(1) 2006 年 1 月 5 日 Rice 発言 (Associated press), 2006 年 3 月 CFR “Russia's Wrong Direction: What the United States can and shoud do", 他。

(2) Energeticheskaja strategija Rossii na perioda 2020 goda, 2000 年。 http://www.ruses.ru/energy/reforma/?article $=45$

(3) Energeticheskaja strategija Rossii na perioda 2020 goda, 2003 年 5 月，45-50 ページ。

(4) 2007 年 12 月 13 日 RBK Daily。 
上記で政府が実際の輸出にどれだけ関与しているかだが，（1）の内需・輸出のバランス達成 （国内価格政策も含め）では内外価格差を考慮した上での原油や石油製品への輸出税賦課（国 際価格に連動，ガスに対しては現在一律 $30 \%$ の税率）で介入していると言える。今後ロシア の原油・ガスへの国内需要増大と国内外価格差の縮小に伴い, 最終的にはこの輸出税は本来廃 止されるべきものであるが，財務省の財政・金融政策の面から 2008 年度以降の安定化基金の 後継基金創設実施に当ってもこの廃止は見込まれてはいない(5)。この輸出税以外に原油・ガ スの輸出量を直接規制する政策は採られておらず，トランスネフチが操業する基幹原油輸送パ イプライン網を通じて行われる原油輸出で生産地からロシア領内の船積港までや直接隣国への 輸送に際し, 四半期毎に産業電力省が各原油生産企業の生産実績を一応の基準として定める各 社への輸送量割り当てを行っているが，これは原油パイプラインの輸送能力の制約が主な理由 で, 政府の輸出介入政策に数え上げられるかは疑問となる。

（2）の輸出先と輸出方法の多様化では，原油の国際商品としての性格やガスの長期契約に基 づく販売により，政府の輸出政策担当主体である経済発展・貿易省と産業電力省（運輸省も加 わる場合もある）(6) が石油企業やガスプロム（ガスの輸出を独占）の輸出先での選定方針に 国策で介入する余地は殆ど無いが，ロシア東部の地域開発から派生する中国・太平洋沿岸諸国 への新規輸出計画には間接的にとは言え大きな影響を与えていると言える。

（3）や（4）に関する外交面では，2006 年 7 月のサンクト・ペテルブルグで行われた G8 サ ミットに向けロシア政府はエネルギー安全保障の考えを打ら出し，その中で世界のエネルギー 市場での無制限な競争を制限し，短期取引ではなく買い手も売り手に引き取り保証を与える長 期契約を重視することで需給の相互保証を実現させる考えを述べているが (7)，これは従来ガ スプロムが行ってきた輸出の契約形態をそれが欧州が推すエネルギー憲章や市場自由化の思想 と相容れないままに追認・援護するに止まっている。また 2003 年の時点で想定されていた外 資の国内資源開発他への参入可能性は 2005 年以降大きく変化し，戦略鉱区を立法措置で設定 することでこれを制限する方向へ進んでいる。

なおエネルギー戦略には規定されていないが, 新規の輸出経路創設, 即ちパイプライン増設 での投下資金額の面では自然独占法によるガスの国内価格や原油・ガス輸送料（tariff）設定の 観点から，トランスネフチ及びガスプロムの年間設備投資額の政府による査定・承認が行われ ていた。しかし，ガスプロムは2006 年から設備投資実施を政府承認抜きで行っている ${ }^{(8)}$

以上が行政府の関わり方だが，原油及びガスの輸送パイプラインを操業するガスプロム及び トランスネフチは共に株主議決権の過半を政府が所有し，政府からの派遣役員が過半を占める 取締役会を通じその最大株主としての方針が経営陣へ指示されていると考えられる。但し，例 えばベラルーシやウクライナへの一時的なガスの供給遮断や表には出せない既存通過国迂回策 などは，それぞれの経営陣と政府首脳との間の公式・非公式双方での緊密な連携を通じて実施

(5) Федеральный закон <<О федеральном бюджете на 2008 год и на плановый период 2009 и 2010 годов $>>$ http://www1.minfin.ru/ru/budget/federal_budget/

(6) 2005 年 12 月に政令にて関係諸官庁・企業・地方政府間の政策調整協議の場として TEK（燃料・電力 部門）政府委員会が創設され，ここに関係中央官庁（上記 3 省に加え天然資源省，反独占省他），ガ スプロムや石油企業, トランスネフチ等の輸送企業, それに関係州政府, 研究機関, 議会上・下院代 表が構成員として集められ，輸出も含めた石油・ガス・電力・石炭に関する各方面の利害関係の調整 を行っている。

(7) 2006 年 6 月 15 ～ 21 日 Interfax /Russia \& CIS Oil and Gas Weekly, Lavrov 発言他。

(8) 2006 年 7 月 12 日 Vedomosti。 
されているのが実態であろう。その中で政府も両社の企業としての採算問題を考慮せねばなら ないが，上記の中国・太平洋沿岸諸国への新規輸出計画では輸出の向け先の多岐化が戦略とし て言及されてはいるものの，むしろ国策としての地域開発が優先して考えられており，2003 年からの原油（及びガス）の国際市場価格の急騰がもし無かったならば，ロシアの石油・ガス 関連企業の資金負担の限界に問題が及び，外資を入れてまで果たして推進すべきか否かの議論 を政府内で生んでいたであろう。

\section{2 欧州向け原油・ガスの輸出一輸送経路・通過国問題}

\section{（1）原油}

2006 年のロシアの CIS 外に向けた原油輸出 2 億 4140 万 $\mathrm{t}$ の流れはドルージバ・パイプライ

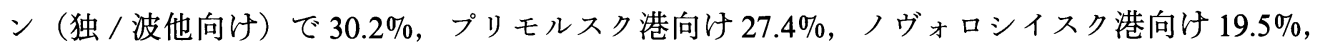
その他港湾及び鉄道で $22.9 \%$ の割合となり ${ }^{(9)}$, 域外輸出全体の $85.5 \%$ が国営企業トランスネ フチのパイプラインにより担われている。

ソ連崩壊後のロシアの原油基幹パイプライン建設実績は, 2001 年まではバクーーノヴォロ シイスクのチェチェン迂回路 $312 \mathrm{~km}$ (2000 年完成) とウクライナ領内通過を迂回するスホデ リナイアーロジオノフスカヤ間 $252 \mathrm{~km} / 1000$ 万t/ 年（2001 年完成）のみであった。何れも輸 送途上での第三国乃至はとれに準ずる地域の経由を回避することを目的としており，この迁回 への動機は政府の施策として明示されはしないものの，1999年 9 月にトランスネフチ社長に ルークオイル社から転じた S.M. ヴァインシュトクが就任して以来（2007 年退任）ロシア政府 及びトランスネフチの最優先事項へと強められている。

今後の原油輸出量の見通しは国内生産量と内需の動向に左右され, 生産面では当面年率 $1 \sim 2 \%$ 程で増加するとロシア政府は見ている ${ }^{(10)}$ が，国内での石油製品価格上昇抑制や産業の 加工度引き上げと言った政策の下で精製量の増加も予想されることから, 総じて大幅な輸出量 の増加は現状では考えられない。従い，原油増産のテンポが急速に伸びた時期（1999～2003 年）に輸出拡大を前提として構想された輸送経路新設案が過去数年で修正され，外延拡張より も上述のヴァインシュトクの方針の下で通過国回避による既存の輸出経路の安全確保に従来以 上に比重が置かれ，その過程で外資も含めた石油企業によるパイプライン建設案（西シべリア 一ムルマンスク）も廃案に追い込まれて行った。

図 $1^{(11)}$ に示すように, BTS パイプライン（後述）の建設により 2001 年で 1500 万 $\mathrm{t}$ を輸出 したラトヴィアのヴェンチピルス経由は 2006 年にはパイプライン輸出から姿を消し（200～ 300 万 $\mathrm{t}$ 程度の鉄道輸送での輸出は残る), ベラルーシ経由を回避する BTS-2 が仮に 2009 年に 完成するならば, 2006 年で欧州向けに 7300 万 $\mathrm{t}$ を輸出したドルージバ・パイプラィン経由は 2000 万 $\mathrm{t}$ 程度に減少することが予想され，プリモルスク港他経由の輸出がその分増える勘定

\footnotetext{
(9) Renaissance Capital/2007 Oil\&Gas Yearbook 他。

(10) 前掲Energeticheskaja strategija Rossii na perioda 2020 goda では2003〜2020年での原油増産を年率 $1.1 \%$ と見ている。MERT の 2007 09 年改訂社会経済発展予测では 2010 年で生産量 5.12 億 $\mathrm{t}$ が予測され, 2006 年の実績 4.81 億 $\mathrm{t}$ から年率 $1.6 \%$ の増加（2006 年 12 月 28 日 RusEnergy）, 又フリステンコ産業 電力相は 2015 年での生産を 5.4 億 $\mathrm{t}$ (年率 $1.3 \%$ 増加）と予測している（2007 年 2 月 6 日 RBK）。

(11) 前掲 Renaissance Capital/2007 Oil\&Gas Yearbook 他。2009 年の輸出量全体及び輸出経路比率はプリモ ルスクとドルージバ以外は 2006 年と変らぬものと仮定してある。
} 


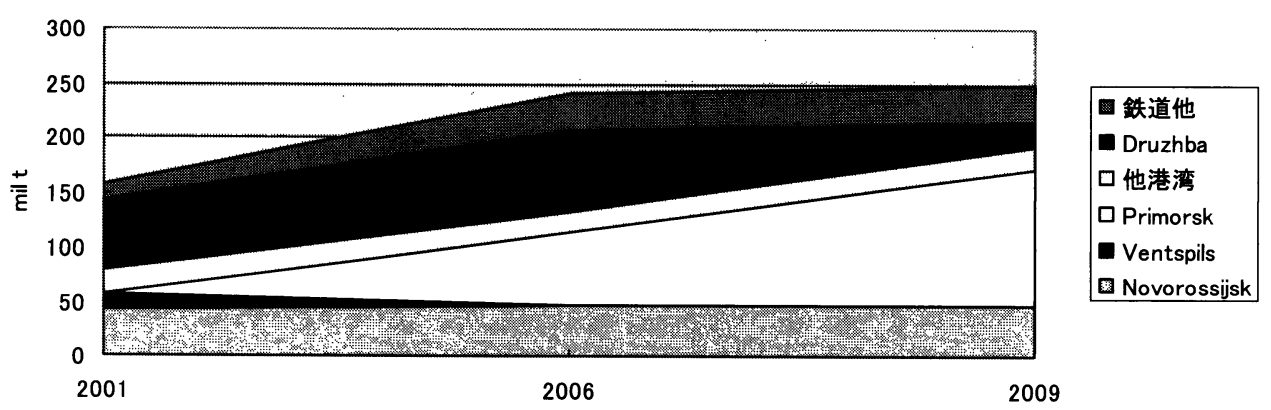

図 1 ロシアの原油輸出経路

(Renaissance Capital/2007 Oil \& Gas Yearbook 他。2009 年の輸出量全体及び輸出経路比率はプリモル スクとドルージバ以外は 2006 年と変らぬものと仮定してある。）

になる。即ち，2001 年で $36 \%$ ほどしか無かった他国を経由しない輸出経路が 2009 年には $80 \%$ を越える可能性があり，欧州向け輸出ではその経路の変化（通過国回避）が 2001 年以降 で際立った特徵と言える。

\section{a BTS パイプライン（Baltic Pipeline System）}

通過国回避策を如実に体現した上述の BTS は, 2001 年末から僅か 5 年弱の間に輸送能力を 1200 万 $\mathrm{t} /$ 年から 7400 万 $\mathrm{t} /$ 年へ拡大し，プリモルスクはノヴォロシイスクを追い抜きロシア 最大の原油輸出港にのし上がった。このパイプラインは，元々は外資主導でチマン・ペチョラ 地域からの原油の搬出経路として 1990 年代に計画されたもので，当時既にバルト諸国との原 油通過輸送で通過料の問題を抱えていたが，自前で設備投資への資金投下を担えるよらな状況 にはなかったトランスネフチが追随する形になった。しかしその後外資・ロシア石油企業・関 係地方政府，融資を期待された EBRD，それに連邦政府の意思統一が一向に図れず，3年ほど 混迷を続けた結果の 2000 年 7 月にロシア政府は最終的に BTS 運営企業のトランスネフチによ る $100 \%$ 出資・所有と操業を認め, 第一期 1200 万 $\mathrm{t} /$ 年の輸送・積出は 2001 年 12 月末に運開 となった。その後 2006 年末までに輸送・積出双方の能力は上記の通り 7400 万 $\mathrm{t} /$ 年へ拡大さ れ，ロシアは結果としてバルト諸国経由での輸出の迁回を達成している。

\section{b BTS-2 パイプライン}

ドルージバ・パイプラインは 2006 年でロシアの原油輸出の約 $1 / 3$ を担っているが，西欧に 行き着くまでにベラルーシ，ポーランド或いはウクライナを通過せねばならない。2006年後 半から 2007 年初めに掛けてのベラルーシとの問題 ${ }^{(12)}$ を契機として, ベラルーシとの国境の 手前ウネチャからロシア国内 $950 \mathrm{~km}$ を経てプリモルスクヘ向から BTS-2 パイプライン建設計 画（輸送能力 5000 万 $\mathrm{t} /$ 年）が浮上した。この BTS-2 は 2007 年前半では夏にも着工とされて いたが，その後原油の向け先をプリモルスクではなく同じバルト海に面するウスチールガに向

(12) 2007 年 1 月 29 日 RusEnergy, 同 2 月 1 日 Neftj i Kapital 他。ロシア政府が 2007 年からベラルーシ向 け原油供給での輸出税免除を廃止することを決定（\$180/t の価格増）したことからべラルーシ側は通 過料の引き上げで対抗し, プーチン・ルカシェンュ両首脳の電話会談で供給価格の増分を\$53に抑え ることで妥協が成立したが 2 日間原油輸送は停止した。 
ける案が浮上し，その線で関連政府令の準備が進められていると報じられる。この完成でバル ト海へのロシア領内からの輸出は 1.25 億 $\mathrm{t} /$ 年前後に拡大するが，これ以上能力を拡張するこ とに問題が無い訳ではない。同海から外洋に抜ける航路に当るデンマーク海峡が浅いために喫 水 $15 \mathrm{~m}$ 以上の船舶（15 万 DWT 以上）の航行は不可能であり, 従いVLCCによる積み取りが 出来ず，又プリモルスク港では冬季の海上凍結が生じその間は Ice class のタンカーしか寄航で きない制約がある。

\section{c 黒海方面への原油輸出}

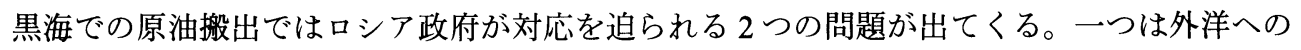
唯一の出口であるボスポラス海峡の輸送量限界であり, 今一つは周辺国と欧州のロシアを迁回 した原油輸送計画の動きであり，この 2 点が絡み合いロシアや他国による黒海周辺での原油輸 送パイプライン新設計画が競合している。

1）ボスポラス海峡の問題

海峡の通過輸送限界量についてこれまで様々な数値が出されており, 条件設定の如何で絶対 的な数值の算出は容易ではないが，物理的に 10 万 DWT 以上のタンカーの航行が難しい中で, 年間 1.5 億 $\mathrm{t}$ を超えるとされる原油及び石油製品の通過輸送では, 悪天候が重なると通過の順 番待ちで 20 日間近くの滞船を強いられ, 昨今の傭船料上昇で滞船料の支払もかなりの額に上 る。またトルコ政府は安全面からの通航規制を実施し, 同海峡の通過量はその通過能力を遥か に超えているとも主張しており ${ }^{(13)}$ ，この海峡を迁回する（黒海を全く経由しないか，或いは 黒海に搬出した後同じ黒海に面する別の港湾に陸揚げする）輸送経路の設定は全体から見れば 避けられない状況にある。

ロシアが加わる海峡バイパス計画は，ブルガリア/ブルガスーギリシャ/アレクサンドロウ ポリス間（259 km, 計画輸送能力 1500 万 $\mathrm{t} /$ 年, 将来的に 3500-5000万 $\mathrm{t} /$ 年）であり, 黒海 沿岸港湾から一旦船舶で積み出された原油を同じ黒海沿岸のブルガス港で陸揚げし，これをパ イプラインでギリシャのアレクサンドロウポリス港へ輸送する案となる。元々は 1993 年にブ ルガリア・ギリシャ 2 カ国で始まった計画に後刻ロシアが参加しており, BTS の場合と同様 に外的与件への対応という同国の受動的な姿勢と言えるだろう。地理的にボスポラス海峡をバ イパス寸るにはロシアの第 3 国通過回避実現は不可能であり，そのためブルガリア，ギリシャ との条件他の折衝に多大な時間を要し, 長引く交渉の末に 2007 年 3 月に 3 カ国政府間協定が 調印され同年 12 月に漸く建設・操業を担ら 3 力国の合弁企業設立が合意された。

ロシアはこのパイプラインを自国原油よりも先にカザフスタン原油に通過経由させることを 狙って括り, この問題と CPC パイプライン（後述）の拡張問題とが絡み合った結果，カザフ スタンは 1700 万 $\mathrm{t} / \mathrm{y}$ の原油投入に合意したと報じられている ${ }^{(14)}$ 。ロシアには海峡通過問題を 念頭に黒海方面への自国の原油輸出量を大幅に増加させる計画はなく，この増加が予想される カザフスタン原油に現在の自国原油の海峡通過量が押し出されかねない場合を想定しその対応 策に出てきている。

(13) 1995 年筆者による Istanbul での聞き取り。最近では “The Turkish Straits Maritime safety, legal and environmental aspects” Turkish Marine Research Foundation, Publication No. 25 ごの問題が触れられてい る。

(14) 2007 年 11 月 27 日 RBK Daily。 
この計画に対抗する海峡バイパス案はトルコ領内縦断パイプライン（サムスンージェイハン 間 $560 \mathrm{~km}$, 計画輸送能力 5000 万 $\mathrm{t} /$ 年) とウクライナからポーランドへ（オデッサーブロデ イープロック間 $1160 \mathrm{~km}$ (新設部分 $490 \mathrm{~km}$ ), 計画輸送能力未定) で，何れも輸送する原油を ぞう確保するかが最大の問題となる。

2）ロシア迁回の原油輸送計画

上記のブルガスーアレクサンドロウポリス間パイプラインは，ロシア領通過ではないものの 操業主体持分の過半をロシアが握ることから，CIS 産油国や欧州は他の対抗案への関心を高め ている。ロシア迂回の CIS からの原油輸送はアゼルバイジャンからの原油搬出で BP 他数社に より建設され 2006 年に稼動開始した BTC パイプライン（バクーートビリシージェイハン間 $1767 \mathrm{~km}$ ，輸送能力 5000 万 $\mathrm{t} /$ 年）で既に始まっており，それ以前に計画・建設されロシア領 内を通過することになったカザフスタンからの CPC パイプライン（テンギズ油田一ノヴォロ シイスク間 $1580 \mathrm{~km}$ ，輸送能力 2800 万 $\mathrm{t} /$ 年）がその拡張計画を巡るロシア側との交渉で様々 な問題 (15) を抱えていることから，その期待が益々強められている。この動きに対しロシアは， 原油価格が現在に比べ遥かに低かった 2001 年辺りまでは世界市場への他の CIS 諸国からの原 油輸出が自国との競合関係に立つとの見方をとり BTC パイプライン計画への対抗案（バクー 一ノヴォロシイスク間拡張）を推進したが，その後は他国の動きは止めようもないとの見方に 変わり, 更に原油価格急騰後はガスの場合と異なり最早この点はロシアにとって大した問題と はならなくなった。

\section{(2) ガス}

ガスプロムが現在所有する欧州・トルコ方面への輸出パイプラインは表 1 の通りとなり，非 CIS 向け輸出能力は 2000 億 $\mathrm{m}^{3} /$ 年を超え, 2010 年迄は輸出増大に対応が可能とされる。

旧ソ連崩壊後に建設されたのは表 1 での(2)の一部（ヤマール・欧州）と (6)（Blue Stream） だが，前者の建設では 1993 年に露波政府間協定に従い開始されたものの，協定に義務付けら

表 1 ガスプロムの輸出ガスパイプライン

\begin{tabular}{|c|c|}
\hline 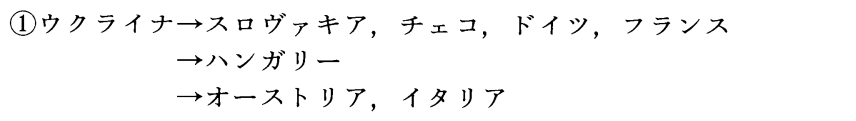 & 輸送能力 1460 億 $\mathrm{m}^{3} /$ 年 \\
\hline 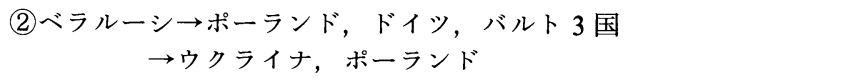 & 輸送能力 330 億 $\mathrm{m}^{3} /$ 年 \\
\hline (3)ウクライナ/モルドヴァ $\begin{aligned} \rightarrow \text { ウーマニア, ブルガリア, マケドニア, } \\
\text { ギリシャ, トルコ }\end{aligned}$ & 輸送能力 240 億 $\mathrm{m}^{3} /$ 年 \\
\hline (4)フィンランド & 輸送能力 60 億 $\mathrm{m}^{3} /$ 年 \\
\hline (5)コーカサス諸国 & 輸送能力 80-100 億 $\mathrm{m}^{3} /$ 年 \\
\hline (6)トルコ（Blue Stream) & 輸送能力 160 億 $\mathrm{m}^{3} /$ 年 \\
\hline
\end{tabular}

（ガスプロム年次報告 2005 年，2006 年，他）

（15）通油料引き上げ，既存債務 $\$ 50$ 億の軽減策，株主融資での金利引下げ，取締役会構成変更，ブルガス /アレクサンドロウポリス間パイプライン建設への参加とその利用へのロシア側要求，など。 
表 2 欧州向けのガスパイプライン新規建設計画

\begin{tabular}{|l|l|}
\hline SEG $\left(550\right.$ 億 $\mathrm{m}^{3} /$ 年 $)$ & $\begin{array}{l}\text { Grjazovets〜 Vyborg }(897 \mathrm{~km}), \text { Vyborg 〜ドイッ /Greifswald }(1189 \\
\mathrm{km}) \text { 間バルト海海底, 将来的にオランダ /Harlingen 延長 }(651 \\
\mathrm{km}), \text { 更に英国への延長。 }\end{array}$ \\
\hline South Stream $\left(300\right.$ 億 $\mathrm{m}^{3} /$ 年 $)$ & ロシア領内黑海沿岸〜ブルガリア $/$ Burgas $(900 \mathrm{~km})$ 間黑海海底。 \\
\hline Blue Stream の増強分 $\left(90\right.$ 億 $\mathrm{m}^{3} /$ 年 $)$ & 現状では実施の可否不明。 \\
\hline
\end{tabular}

(諸報道記事より筆者作成)

れた必要投資をポーランド側が実施せず工期は大幅に遅れ，同国領内での輸送能力 330 億 $\mathrm{m}^{3}$ / 年の達成は当初の計画から 10 年近く遅れた 2006 年となった。この遅れの根底には, 通過パイ プラインの敷設がポーランドの対ロシア・ガス依存度上昇に直結することを当時の同国政府が 警戒していた ${ }^{(16)}$ 面が挙げられ，これに同国内輸送通過料，投資義務の両国間割り振り，さら にポーランドのガスプロムからのガス長期輸入契約条件変更を求める動きが加わり, 交渉が度 重なり長引いた。このヤマール・欧州線建設での問題や, 同じ通過国のウクライナでの未払い や盗ガス問題の繰り返しは, 安定した輸送ルートの確保を欠けば結局はとれが新規生産計画の 大きな阻害要因として跳ね返ってくる深刻さをガスプロムに認識させ, 原油輸送の場合と同様 に通過国回避の視点を重視したトルコ向け Blue Stream（ベレゴヴァヤーサムスン間 $446 \mathrm{~km}$ ） の建設に同社を向かわせ， ウクライナ領迁回は当然のことながら，同じ理由で技術的に容易な グルジア経由の陸路も取らず前例の無い黒海海底深度 $2000 \mathrm{~m}$ のパイプライン敷設が実施され た。

今後新たに建設が計画されている欧州向けのガス・パイプラインは表 2 の通りで，その中で 最初に計画が始められた北欧パィプラィン（SEG）で見れば，2001年の段階で既にガスプロ ム内部で通過国迁回は新設での基本原則となっていたことが理解される。

\section{a 北欧パイプライン (SEG)}

予定より 1 年遅れの 2009 年の着工が現在の目標とされ，この建設に必要な外国製諸資機材 輸入契約も 2007 年 11 月現在で完了している。2005 年 9 月にガスプロムと BASF/E.ON の独 2 社との建設に関する 3 社基本合意書が調印され，これら 3 社による Nord Stream 社（当初は NEGPC 社）の設立が合意された（後にオランダの Gazunie も参加）。

この計画は従来のウクライナ，ベラルーシ，ポーランド或いはバルト諸国などの通過国を経 由せずロシア領から直接西欧へガスを輸送するものであり, 同時にガスプロムはヤマール・パ イプラィンの増設案を取り止めている。これに対しこの案が具体化し始めた頃からポーランド 及びバルト 3 国は建設への反対論を展開し（後にラトヴィアは反対論を引っ込める），ロシア /ウクライナ間でのガス供給問題が生じた 2006 年初頭以降は主として環境問題を理由として

(16) ポーランドは 1996 年にガスプロムと 25 年間のガス輸入長期契約を締結したが, 他方でロシア以外の ガス源を求め, ブゼク首相の時代にデンマーク, 独からの輸入契約を行い, 2001 年 9 月には 1999 年 から開始したノルウェーからの少量のガス輸入を長期大量輸入契約へ拡大し, ロシアからの輸入量の 過半をこれに置き換えようとした。この契約に至る過程で同首相は“ロシア以外からのガス調達と言 510 年来の念願が叶った”（2000年 7 月 30 日 AP） と述べている。しかし，その後このノルウェー からの輸入は新規にパイプラインを建設せねばならず, 又ロシアからの輸入に比べ価格が高いために 結局取り止めとなった。 
スウェーデンもこれに加わり, 推進に賛成の立場を採るドイッ・フランス・イギリス・オラン ダ他の EU 主要国との EU 内の見解調整の問題も大きく浮上している。

\section{b 南欧ガスパイプライン（IUEG）}

2005 年 7 月にプーチン大統領は新たにトルコ及び更にその南のイスラエルを念頭に置いた パイプラインの建設構想を明らかにした。既存の Blue Stream の能力をを 80-160 億 $\mathrm{m}^{3}$ / 年分 増強する案で現在の低稼働の解消も担うことが期待され，同年年 11 月にロシアはトルコを経 由してのイスラェル及び南欧へのガス供給の基本線でトルコ側と合意した。しかし，トルコに は自国をコーカサス, 中央アジア，あるいは中東やロシアからのガスの欧州向け一大輸送ハブ とする思惑があり，基本合意に続くガスプロム・Botas 間の具体的交涉では双方の利害が対立 した。トルコ政府・Botasは，ガスプロムに対し通過料などの問題に加え，ガスの仕向け地制 限撤廃を要求した模様で（即ちどの第三国へどれだけガスを売るかの権利をトルコが事実上持 つ立場の要求)，これはガスプロムの全く受け入れられないところから膠着状態の後に同社は トルコの意表を突き， 2007 年 6 月に黒海海底をロシア領からブルガリア沿岸迄走る海底ガス パイプラインの建設に付きその意向書をイタリアの Eni と調印した。この計画が通過国のトル コを外しロシアから直接 EUへのガス輸送を行うことを意図して居ることは明白であり，その 点では北欧パイプラインと同じ考えに立脚していることになる。

\section{c ロシア迁回のガス輸送計画}

上記の南欧パイプラインは，原油の場合と同じくロシアを迁回するCISからのガス輸送を 狙ら計画と競合する。2005 年 6 月に Botas, Bulgargaz, Transgaz, MOL, OMVの 5 カ国のガ ス輸送企業がイラン/アゼルバイジャン/カザフスタン/トルクメニスタン/エジプト/イラ ク /シリアからの将来的な欧州向け輸送を目的とした事業推進企業 NABUCCO を設立し， 口 シアからのガスへの依存度を軽减させることを目標とする EU 及び米国もこれを援護してい る。当初は主としてイランからのガスを対象に考えていたが，核問題での同国と西側の対立か らこれが難しくなり，当面はアゼルバイジャンにガス源を求める前提で検討が進められてい る。しかし，アゼルバイジャンーグルジアートルコーブルガリアールーマニアーハンガリー一 オーストリアの経路 (17) で輸送規模 310 億 $\mathrm{m}^{3}$ / 年のガス輸送を満たすにはアゼルバイジャンの ガスだけでは到底足りず，このためカスピ海の海底を通りトルクメニスタンからのガスも取り 込むパイプラインの敷設を $\mathrm{EU}$ ・米は推進している。この最大の障害はカスピ海沿岸諸国の同 海海底利用に付いての法的合意が未だに出来上がっていない点で，ロシアは EU・米の動きに 先んじ海底利用には沿岸国全ての同意を必要とする，との合意を 2007 年 10 月に取り緾め，実 施に際しロシアとイランが合意せね伎着工が難しい環境を構築している。

このように, NABUCCO パイプライン計画はガス源確保で問題を抱えており，この計画の 経路が南欧パイプラインでロシアが検討している上記のブルガリアから北西に向けた案と略同 じであることから，ロシアのガス流入の可能性に付いてもロシアは否定していないが，これは

(17) アゼルバイジャンはShah-Deniz ガス田開発での第一期生産 (第一期 86 億 $\mathrm{m}^{3} /$ 年, 第二期 160 億 $\mathrm{m}^{3} /$ 年) 開始に合わせで Bakuからトルコ/Erzurum 迄の南コーカサス・パイプラインを建設し（アゼルバイ

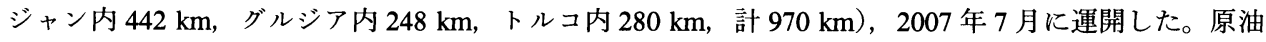
のBTCパイプラインに続き旧ソ連領内からロシアを迁回しトルコ方面に向からガスの輸出経路が初 めて誕生したことになる。 
計画のそもそもの目的に適合せずとなる。だが, 原油パイプラインと異なり EU 内ではガスパ イプラインの操業に対し今後益々生産と輸送の分離などの厳しい条件が課せられて行くものと 見込まれ，ガスプロムも EU 内でのガス輸送設備への同社支配が不可能となれば，EUが受け 入れられるよらな何等かの形で NABUCCO に加わる可能性も残されている。

\section{3 アジアへの原油・ガス輸出計画}

欧州方面への原油・ガス輸出政策が，ロシアの既存輸出市場維持を目的とする言わば「受 身」の発想に基づいているとすれば，アジアへの進出は新たな輸出市場開拓・確保の意味で攻 勢型とも見える。相手は中国, 朝鮮半島, 日本を始めとした米・豪も含む環太平洋諸国であ り, 未染手の新市場開拓とそれに伴ら開発・生産の具体化は $1960 \sim 70$ 年代のガスの西欧向け 輸出開始以来の大規模な新企画ともなる。しかしその本来の目標は輸出増加あるいはその仕向 け先の多岐化よりむしろ国内東部の開発推進に置かれ, 新規産出資源の国内市場が東シベリ ア・極東では限られるために輸出に向かわざるを得ないとの図式となる。従い開発の政策や実 施の過程如何で輸出可能な原油・ガスの量が規定され，その開発計画が壮大な事業であるため にロシア内部で取り進め方法に付き議論百出となり, 政府主導の色彩は 2001 年から徐々に明 確になってはいるものの今後も方針が左右に摇れ易いことが予想される。具体的には対中，対 朝鮮半島, 対日での政策の中で原油・ガスの輸出をどう位置付けその経済効果の最大化をパイ プライン経路設定によりどう図るか，或いは資源の国内での加工度を高めると言う命題の中で 原油での精製処理拡大, ガスでの GTL 生産, 双方での国内化学品生産との組み合わせをどこ まで行うか,などの問題を抱えている。

\section{（1）原油一VSTO（東シベリア/太平洋パイプライン)}

\section{a VSTO の建設}

中国や太平洋岸への原油輸出構想は 1990 年代から幾つか現れ，その中で今では完全に消滅 したユーコスが 1997 年からこの輸出構想の下で西シベリア東端から東シベリア・極東に掛け ての石油資産を買収し，中国政府やロシア政府を巻き込み 2002 年にアンガルスク一大慶間の パイプライン敷設に付き建設案を緾めた。現在トランスネフチがとり進めているVSTO の建 設は, このユーコスの計画に対抗する形で 2001 年に検討が開始されたもので, ユーコス自体 やその対中原油輸出構想が潰える中で政府の東シベリア・極東の開発案を牽引する事業として 大きく浮上している。ここでも民間企業に原油の輸出は任せないとのヴァインシュトクの思 想 ${ }^{(18)}$ が色濃く反映されていたと言えるだろう。

検討開始から政府の最終認可取得と第一期工事区間（タイシェットースコヴォロジノ間 $2757 \mathrm{~km}$, 輸送能力 3000 万 $\mathrm{t} /$ 年）の着工までに 5 年余を要した理由は, 本件を近い将来で支 えねばならない東シベリアの原油生産見通しが中々付かないこと ${ }^{(19)}$ や環境問題に起因する経 路修正変更, 更に 2003 年後半から始まった国内での鋼管他の鉄鋼製品の急激な值上がりによ

(18) 2003 年11月 26 日 Vedomosti，2004年3月19日 Kommersant Daily/ヴァインシュトクヘのインタビュー。

(19) 第一期で必要となる 3000 万t/年はヴァンコール / タラカン / ヴェルフネチョンスコエの 3 油田を主 カとし, これに不足分は西シベリアからの原油で補ら線で何とか必要量を確保する計算は立ちつつあ る。 
る資機材調達の予想金額上昇に求められる。

第二期のスコヴォロジノーペレヴォズナヤ間 $2013 \mathrm{~km}$ （輸送能力 5000 万 t/ 年）の建設準備 も既に開始されており，建設申請書（TEO）を 2007 年内に政府へ提出予定とトランスネフチ は述べている。しかし，以下の通り具体面では数多くの未決問題が残されている。

・未だに東シベリアから第二期分を満たすだけの原油が出て来るのかは否かは公式に明ら かにはされていない。

・東シベリアの油田は随伴ガスの排出量が多く, この処理方法が固まらぬと原油生産を大 幅に増加する事は難しくなり，油田開発と同時にガス田開発も進め，ガス・パイプラィ ンを敷設し随伴ガスを取り込むことは恐らく不可欠で，これは地域全体の開発計画に結 び付かざるを得なくなる。

・パイプラインと競合する鉄道の側からの建設延期論。

・建設コストは当初予測の $\$ 50$ 億を大きく上回ることは間違いなく，トランスネフチも現 在この点についてのコメントを控えている。

\section{b 中国・太平洋沿岸諸国向け輸出}

対中輸出計画ではスコヴォロジノから中国との国境への支線建設の設計作業が中国からの資 金供与を受けて行われているが，パイプラインでの原油輸出価格を巡って露中間での見解が対 立し支線建設実現に多大な時間が掛かっている。ロシア側の姿勢は対中輸出は行うもののそれ のみへの依存は絶対に避ける，との点で恐らく今日まで一貫して居り，このことも交渉に時間 を要する理由となっているものと思われる。

一方, 太平洋側での原油積み出し設備は第一期工事に合わせ建設される予定であったが, 2007 年 12 月に漸くコジミノでの建設準備が開始された段階で, 更にロスネフチが計画する極 東での新規製油所建設（精製能力 2000 万 $\mathrm{t} /$ 年を 2012 年迄に 1000 万 $\mathrm{t} /$ 年, 第二期工事完了 に合わせ更に 1000 万 $\mathrm{t} /$ 年）が実現すればスコヴォロジノから将来 5000 万 $\mathrm{t} /$ 年の原油が東に 向かっても, 既存の 2 製油所（コムソモリスク・ナ・アムーレ, ハバロフスク）向けへの供給 も含め原油輸出は最大でも 2000 万 $\mathrm{t} /$ 年でしかなくなる可能性がある。

\section{(2) ガス}

\section{a ガスプロムの計画}

東シベリア・極東でのガスの開発と輸送の計画策定の指示をガスプロムが政府から受けてか ら 5 年近くを経て政府の TEK 政府委員会が 2007 年 6 月にガスプロムの原案に基本的承認を与 えたことで具体化へ一歩進み，これを補強する燃料電力省の省令も出された。これまでに公表 されている計画内容を緾めると凡そ以下のよらになる ${ }^{(20)}$ :

1）開発対象: サハリン, イルクーック，ヤクーチャ, クラスノャールスクの 4 地域でのガス 生産と加工。

(20) 2007 年 6 月 26 日ガスプロム press release, 2007 年 9 月 7 日 RBK Daily 他。イルクーツク（コヴィクタ・ ガス田）とヤクーチャ（チャヤンディンスク・ガス田）の生産開始は2016-2017 年に設定され，サハ リンからの LNG 輸出は 2020 年で 210 億 $\mathrm{m}^{3}$, 中国・韓国向け輸出は 2020 年から $250-500$ 億 $\mathrm{m}^{3}$ が見 込まれている。この他にサハリンを除く 3 開発対象地域では夫々へリウムの地下貯蔵と加工も計画さ れている。 
2）輸送経路 : サハリン（S-1）から大陸側国内，中国・韓国向け輸送パイプライン

ヤクーチャからハバロフスクへのパイプライン

イルクーツク，クラスノヤールスクと既存基幹ガスパイプラインとの将来的な

接続可能性

サハリン（S-2）からの LNG 輸出拡大

ここでは外資が主導してきたコヴィクタ・ガス田及びサハリン（S-1）からの中国向け輸出 計画が，何れも国内供給優先他を理由とするガスプロムの反対で頓挫し懸かっている。

\section{b 中国向け輸出計画}

2006 年 3 月のプーチン大統領訪中の際に 2011 年からの対中ガス輸出が合意された。輸出開 始から 5 年程の間で輸出量を 680 億 $\mathrm{m}^{3}$ まで拡大する計画で, パイプラインは西シベリアから 中国内西気東輸へ接続する西回り（ロシア領内 $2700 \mathrm{~km}, 300$ 億 $\mathrm{m}^{3} /$ 年） と, サハリン（S-3 からのガスを想定）から極東経由の東回り（380 億 $\mathrm{m}^{3} /$ 年）の 2 通りで進め, 前者は 2008 年 着工で運開目標を 2011 年とし，それを数年追って後者の輸出も開始される構想であった。

しかし，露中間でガス価格に付き 2007 年 12 月現在合意に達しておらず，従い未だ着工の目 処は立っていない。西シベリアからの場合のガス源を何処に求めるのか（対欧輸出増加計画と 並立できるのか）の問題に対しても明確な説明は未だガスプロムからなされていない。最近は S-1 からのガスに付き極東・東シベリアでの国内ガス需要を満たしてからでなければ輸出はで きないとロシア側が言い始めて招り (21), 国内の地域開発（家庭用ガス供給や化学などの新規 ガス加工）計画に輸出が足を引っ張られる形になってきている。

サハリンからのパイプラィンはガスプロムがハバロフスク/ヴラジヴォストク間を今後建設 し中国領へ向ける他に北朝鮮・韓国への延長も検討されている。中国内部にしか出口の無い輸 送に対しての危険性をロシアが無視してパイプライン計画を進めているとは考えられず，中国 と朝鮮半島の 2 万向への輸出経路確保が実施の条件となるだろら。同様に西シベリアからのパ イプラインも着工となれば何時でも内需と欧州向け輸出にガスの流れを切り替えられるよう設 計されることが考えられる。

\section{4 ロシアが原油・ガスの安定供給国となる可能性}

2006 年初めのウクライナへのガス供給遮断策が欧州にロシアの資源供給国としての信頼性 に疑問を抱かせたことは確かであり ${ }^{(22)}$, 更にロシアの特に長期の国内原油・ガス資源開発計 画が消費国側へ十分に明らかではないことから，今後の世界市場への安定供給を支えるだけ生 産が維持されるのか，との疑問も生まれている。問題は輸出政策のみならずロシアの国内生産 体制へも及び，本稿ではその詳細に触れる余裕は無いが多くの予測の中で今後原油とガスの生 産量が大幅に増加とする向きは見当たらず，そのためにそれらの中国・太平洋沿岸諸国向け輸 出構想やガスでの LNG で新規市場拡大が進められた場合, それを生産増加分だけで賄えるの

(21) 2007 年 11 月 20 日 RIA Novosti ガスプロム/メドヴェデェフ会長発言。

(22) ロシア/ウクライナ間のガス取引には 1990 年代のウクライナ側の未払いや盗ガス問題など, 2006 年 初めのロシアのガス供給遮断を一概に批判できない背景も有るが本稿ではその詳細には立ち入らな い。 
か或いは既存の輸出経路・向け先の変更も伴らのか, が問われる訳である。電力・石油製品の 内需増大とそれらへの供給増加も考慮した上でのロシア政府の新たな原油・ガス輸出量長期見 通しは，1節で触れた 2008 年末に策定予定の「2030 年までのエネルギー戦略」を待たねばな らない。

この中で LNG の生産が将来ロシア内の東西で総計 $4000 \sim 5000$ 万 $\mathrm{t} / \mathrm{y}{ }^{(23)}$ の能力を持つなら ば，現在のガス輸出総量の $1 / 3$ を超える規模となり無視できない存在となるが，この実現には 相当な時間が必要とされ，又世界の市場動向如何で建設計画の全てが実現されるとは限らない ことから，ガスでの新たな輸出経路としての意味合いの方が当面は大きい。1990年代に始 まった LNG 生産の検討は, 当時はヤマール半島からのガス輸送でポーランドなどの通過国を 回避することが動機になっていた。その後世界のガス市場で拡大が見込まれる LNG 取引への 参入を目指し同社のシュトックマン・ガス田開発計画に LNG 生産が結び付けられ，輸出先も 欧州のみならず米国もその構想に加えられた。更にアジア・太平洋地域に対しては, 同社が参 入を果たしたサハリンでの S-2 の生産規模を将来的に 2 倍に拡張し, 能力 2000 万 $\mathrm{t} /$ 年近くの 世界的な LNG 生産基地とする構想を持っている。

こうした計画はガスプロムがこれまで手掛けた経験の無いLNG 分野への進出として企業の レベルで先ず決められているが，今後世界の LNG 生産者と消費者の数が更に増大して行けば 短期契約での取引増加が予想され, 従来の長期契約のみでのガスプロムの世界市場との関り合 いに大幅な変更が強いられる可能性もある。原油と同じ世界的な自由取引市場がガスでも若し 形成されれば，ガス生産者側に立ち価格維持を狙う組織を立ち上げる可能性も否定できない。 しかし，実際のガス取引の赹勢から見てもこの可能性はかなり先の話であるだけに，このいわ ゆるガス版 OPEC 創設可能性が LNG の輸出経験すらまだないロシア政府の当面の主要政策に 含められているとは考え難い。

原油・ガスの国際価格への自国の影響力行使にロシア政府・企業が踏み切った例は未だ出て いない。現在ロシア原油の取引市場創設を経済発展・貿易省は進めているが，生産国側に立ち サウジアラビアのように swing producer の役割を演じることも，あるいは消費国の資本が自由 に自国の資源開発に参画することで間接的に供給保証や国際価格に影響を与える姿勢も採って はいない。前者では原油の生産余力がサウジアラビアほど大きくは無く，その総生産量の過半 を民営化された複数企業が担っていることやガスの長期契約の価格算定方式が現状では原油価 格に連動した形になっていること，後者では国内資源への外資の支配を忌避する方針がそれぞ れの理由であり，政府・企業共に国際価格を外的条件として报っているこの状況にも当面変化 は予想されない。これ等の点からロシアの輸出行動は資源大国でありながら世界市場に対し寧 ろ受動的と評されよう。

\section{結 語}

欧州向け原油・ガスの輸出で進められているロシアの政策は通過国迂回で特徵付けられ，一 方, 中国他太平洋沿岸諸国への原油・ガス輸出は国内地域開発の結果として出て来る動きでも

(23) シュトックマン・ガス田開発に伴らムルマンスク近辺での 750 万 $\mathrm{t}$ 年, サハリンでの $\mathrm{S}-2 / 960$ 万 $\mathrm{t}$ / 年 (S-2でのプラントは略完成) が先行し，ムルマンスクでは能力 4 倍増, サハリンではその倍増が 将来構想として出ている。 
あるために，ここでも輸出面でのロシア政府の基本方針と呼べるものは将来的な輸出量の増加 と言った形でしか未だ表されていない。何れにおいても原油・ガスの輸出をその対象国への何 等かの政治的目的と結び付けて国策として実施されている，と言った形は浮かび上がって来 ず，中国向けの輸出構想を例にとり対中関係強化の一環としての計画とそれを捉えようとして も, 輸出価格の問題で話が実際に進まない状況ではこの計画を国策と呼ぶには躊躇させられ る。資源大国に求められるのは，今後増大する原油・ガスの世界市場の中でそれが生産側・消 費側何れに傾くかは別として 10-20 年後を見据えた自らの可能性と立場を明示することであ り，これが不透明な間はロシアが安定した供給者としての信頼を得ることは簡単ではないもの と思われる。

（本論は複数レフェリーの審査を経て編集委員会が採択したものである。） 